\title{
Bushmeat Commercial Circuit in Kisangani Region: First and Second Levels of the Bushmeat Supply Chain, on Ituri Road, DRC
}

\author{
Kasereka Vitekere ${ }^{1,2,3 *}$, Consolate Kaswera Kyamakyaa ${ }^{3,4}$, Jonas Kambale Nyumu ${ }^{2,3}$, Yan Hua ${ }^{5}$ \\ ${ }^{1}$ Faculty of Sciences, Department of Environment and Climate Change Management, University of Goma, Goma, \\ Democratic Republic of Congo \\ ${ }^{2}$ Research Center for Environmental Planning, Goma, Democratic Republic of Congo \\ ${ }^{3}$ Faculty of Sciences of the University of Kisangani, Kisangani, Democratic Republic of Congo \\ ${ }^{4}$ Centre de Surveillance de la Biodiversité, Faculty of Sciences, University of Kisangani, Kisangani, \\ Democratic Republic of Congo \\ ${ }^{5}$ Guangdong Provincial Key Laboratory of Silviculture, Protection and Utilization, Guangdong Academy of Forestry, Guangzhou, \\ China \\ Email: *vitekere@unigom.ac.cd
}

How to cite this paper: Vitekere, K. Kyamakya, C.K., Nyumu, J.K. and Hua, Y. (2021) Bushmeat Commercial Circuit in Kisangani Region: First and Second Levels of the Bushmeat Supply Chain, on Ituri Road, DRC. Open Access Library Journal, 8: e7988.

https://doi.org/10.4236/oalib.1107988

Received: September 21, 2021

Accepted: October 26, 2021

Published: October 29, 2021

Copyright (c) 2021 by author(s) and Open Access Library Inc.

This work is licensed under the Creative Commons Attribution International License (CC BY 4.0).

http://creativecommons.org/licenses/by/4.0/

\section{(c) (i) Open Access}

\begin{abstract}
Many forest households closely depend on wildlife resources and their current exploitation does not guarantee sustainable management. A huge quantity of bushmeat is transferred from hunting areas to the Kisangani market for commercial purposes. It is useful to know how this activity is conducted and who the actors are. Actors (42 hunters and 13 wholesalers) were interviewed, and focus groups were done. Regular visits to 22 hunters throughout a two-month period were done, for data collection. Two hypotheses were brought out: 1) actors in this supply chain do not know national legislation about protected species and are only illiterates; 2 ) the supply chain is a simple transaction between hunters and sellers. Findings revealed that actors within the bushmeat supply chain have diversified profiles according to age and education level, which was widely varied: illiterate, primary-secondary school and university and have a good level of knowledge about national legislation on protected species. The commercial circuit is complex and has many directions. Wholesalers have a major role in this supply chain. Their transactions are the most important according to both frequency and financial profitability. Hunters and wholesalers have associations that do not definitively establish regulations within the supply chain. Financial profitability is the primary reason that leads hunters to sell their game. The results demonstrate (by Student's t-test) that hunting activities have a negative effect on animal diversity. Efforts should be undertaken to attain the strict respect for law that will make this activity more sustainable.
\end{abstract}




\section{Subject Areas}

Conservation Biology

\section{Keywords}

Actors, Bushmeat, Hunters, Wholesalers, Sustainable Hunting,

Democratic Republic of Congo

\section{Introduction}

Wildlife resources constitute a major source of subsistence for forest communities in central Africa [1] [2] [3] [4] [5] particularly, and hunted and locally sourced bushmeat significantly contributes to the diet and household income within the Congo basin [6] [7] [8] [9]. For example, in the Democratic Republic of Congo (DRC), bushmeat generates a net economic revenue of US\$91 million per year [10]; 16.1 billion per year CFA franc (equivalent to US $\$ 28.37$ million; CFA: French Colony of Africa) in Cameroon [11] only the pk 12 (kilometric point) market in CAR (Central African Republic) about 7.6 million of euros (US\$ 8.7 million) per year [12] representing almost one percent of the country's gross domestic product. It remains the primary source of animal protein for the majority of families in the Congo basin [12] [13] [14] [15] [16] thus hunting has become a ubiquitous activity for livelihood for many households in the region [17].

The exploitation of wildlife for bushmeat for both subsistence and commercial sale leads to numerous concerns, notably regarding the long-term sustainability of this practice as it relates to wildlife populations [10] [18] [19]. Indeed, unsustainable hunting modifies richness species and animal density [6] [17], can lead to local extinction of the most vulnerable species, for example, great apes [20], and a reduction in regional biodiversity [18] [21] [22] [23], it causes density changes in big size animals that are seed dispersers and sometimes predators that regulate ecological equilibrium [24] as $60 \%$ of species are hunted unsustainably in the Congo basin [25]. In previous findings, researchers used the term "empty forests" to describe this scenario, where the habitat itself is relatively intact when many of its larger vertebrate species are rare or absent [26].

Since the 2000s, there has been an increase in commercial bushmeat exploitation that is oriented toward urban areas, even extending to mining concessions in the forest [27] [28] and hunting patterns have changed rapidly [29]. Such exploitation is a particular threat to wild fauna because of the variety of the devices to be used, the frequency of taking, and the lack of sustainable hunting practices in age class selection and hunting season restriction [30].

Over the past 20 years, this thriving bushmeat trade has alerted natural resource managers, and the bushmeat supply chain becomes an increasing focus of scientific research [31]. Knowledge of the structure and function of the full 
supply chain in local and regional bushmeat trade operations is the key to the potential management of this threat to wildlife populations [6]. Three levels can be identified in this supply chain. Hunters represented the first, who decide whether or not to sell. The second is represented by wholesalers and retailers, both in urban and rural markets, who purchase the game from hunters. The third involves the types of consumption and city governance, as well as quantities, laws and management [1].

Some levels of this sector remain less studied, like the sale of cooked bushmeat, international export and the mediators between hunters and urban consumers [11]. The latter issue is particularly challenging to address as urban residents enjoy bushmeat in their diet. However, they rarely think about the mechanisms occurring in the hunting villages that allow the regular cities' supply [1] [3] as the commodity chain remains less studied [6]. Therefore, it is useful to carry out researches on the first actors in the commercial circuit (hunters) as well as the intermediaries (wholesalers) between hunters and urban consumers.

The objective of this study was to 1) document the level of hunters' knowledge according to Congolese hunting legislation (especially protected species); 2) evaluate the rules and sale transactions of the bushmeat supply chain as well as the wholesalers' role within the chain 3 ) determine the incentives factors for the sale of game by hunters; 4) attempt to find if the hunting activities impact animal diversity within the Kisangani region in the DRC.

\section{Materials and Methods}

\subsection{Study Area}

The study sites were the villages of Bafwaboli, commonly known as "pk 122" (coordinates: $00^{\circ} 37^{\prime} 41.3^{\prime \prime} \mathrm{N}$ and $026^{\circ} 06^{\prime} 57.1^{\prime \prime} \mathrm{E}$ ), and Baegofuma (coordinates: $00^{\circ} 46^{\prime} 19.6^{\prime \prime} \mathrm{N}$ and $026^{\circ} 15^{\prime} 25.8^{\prime \prime} \mathrm{E}$ ), commonly known as "pk 147" (Figure 1).

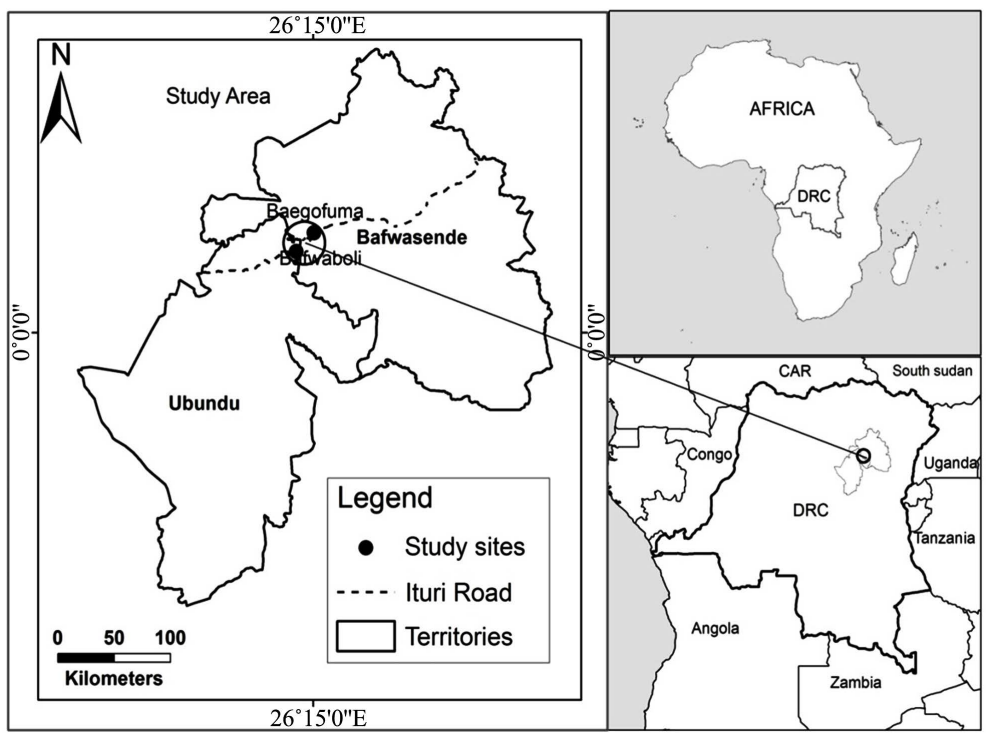

Figure 1. Study area. 
Bafwaboli and Baegofuma had respectively 9409 inhabitants in 2014 and 9000 inhabitants in 2008, (chief of villages, pers. com.). The ethnicity varied within these villages: Bali, Bangu, Kumu, Lokele, Manga, Mbole, Mongo, Rumbi, Nande, Ngando, Ngelema, Turumbu. They are located on Ituri road in the province of Tshopo, in the Democratic Republic of Congo and the closest city to them is Kisangani (distant 122 and $147 \mathrm{Km}$ ). Their economic activities are agriculture, hunting, fishery, and some commercial activities. The original vegetation of this regional (which is a Congo basin region) has been beforehand described [32].

\subsection{Materials}

Biological materials were various carcasses of game, included mammals, birds and reptiles. They were inventoried while paying a regular visit to hunters returning from the forest, in order to document with precision hunting activities. The list is found in appendices (Appendix 1) with more details according conservation status.

\subsection{Data Collection}

Interviews of both hunters and wholesalers were conducted. Hunters were randomly chosen. If two or more hunters were found in the same household, they were interviewed separately in order to collect different point of views. Wholesalers were interviewed in a range of situations, when they were: 1) waiting or looking for hunters in the village; 2) purchasing game where they encountered hunters; 3) at their homes; 4) in restaurants. A sample of 42 hunters and 13 wholesalers were interviewed using local language (Kiswahili and Lingala). Focus groups were also carried out so their different points of view could be assembled. The procedures followed in gathering data were in accordance with ethical standards, and interviewed participants provided both oral (individually) and written (conducted by a legally authorized representative) consent. To record more detailed information about each hunter's take rates and species hunted, regular visits were paid to 22 hunters throughout a two-month period; then all species captured and the circumstances of each bushmeat sale were recorded. Walking time was used to express distance.

\subsection{Data Analysis}

To interpret information about actor profiles, different transactions between hunters and buyers, game sold and needs covered by hunting incomes, the percentage was calculated. Analysis and interpretation of the qualitative data explained some facts within this activity. To determine influence of education level and detention of valid hunting permit on the knowledge of protected species, a multiple correlation test in SPSS was run, and a Student's t-test in R console determined the effect of hunting activities on animal. Hunters were asked how far from the villages they could encounter animals, especially large and medium-sized 
mammals in the 1990s and how the situation was during the data collection period. To obtain reliable statistics, 22 hunters were consistently asked, whom we paid regular visits, how far from the village they caught (killed) first animal. Thus, there were three kinds of data for this component: the first from interviews regarding the 1990s, the second from interviews regarding the data collection period and the third from field work in the year which data collection occurred.

Three student tests were conducted (data1 - data2 a paired test; data1 - data3 an unpaired test and data2 - data3 an unpaired test). The first test shows a general trend for the situation, the second presents the determination of whether or not hunting impacts animal diversity, and the last demonstrates the degree of credibility of the second test. The strength of a transaction between different actors in the supply chain was based on quantities of bushmeat transacted through them. Kingdon guides to African mammals [33] [34] were used in species identification.

\section{Results and Discussion}

\subsection{Actor Profiles}

All hunters were men whose age presented a large gap between the youngest and the oldest in an interval of 20 to a little over 60 years and 20 to 49 years for wholesalers (Figure 2). The mean age for hunters was 39.28 and 33.07 for wholesalers, with standard deviations of 10.38 and 5.25 respectively.

We realized that hunting is a high-risk activity, demanding in technical skill and in physical strength.

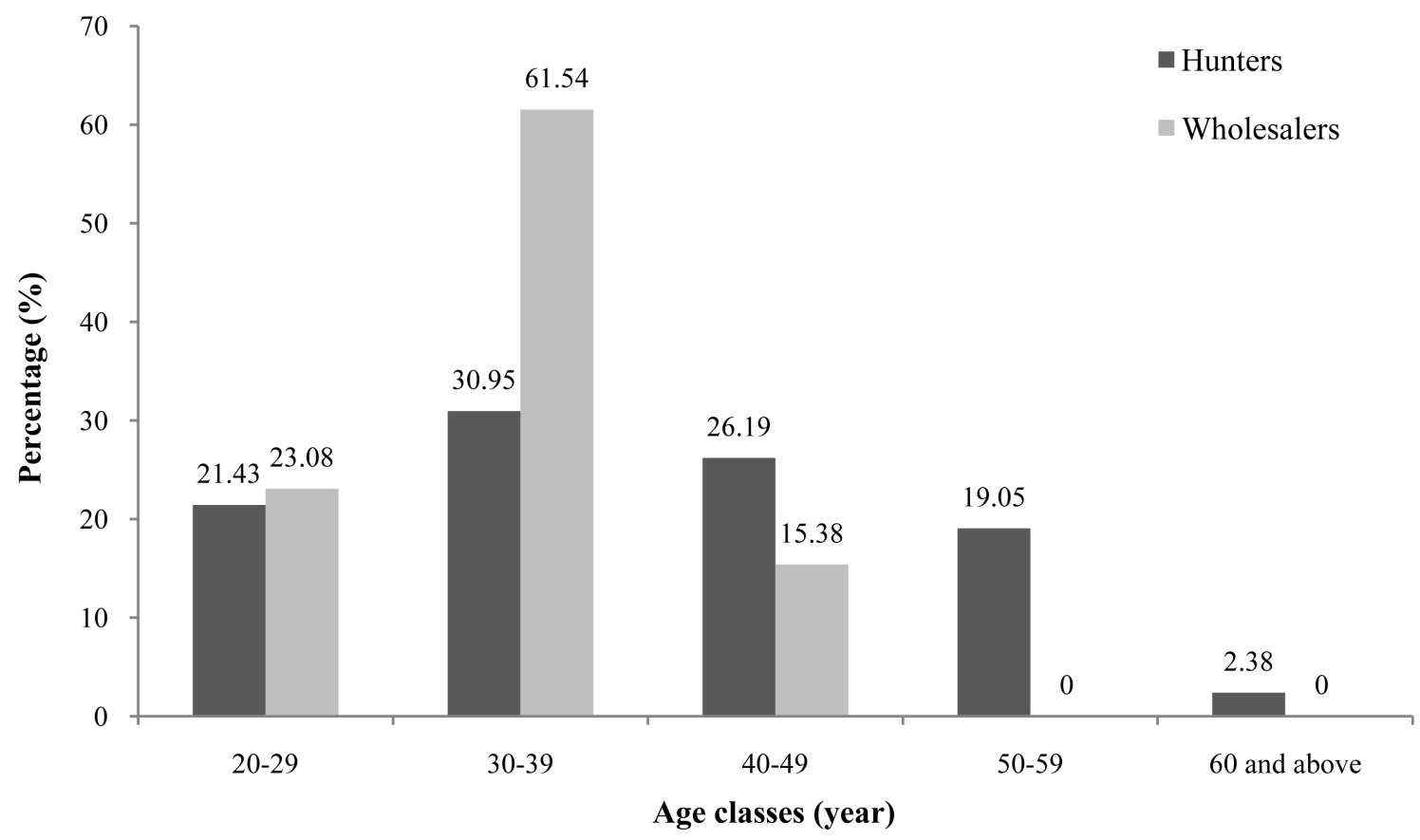

Figure 2. Age of actors of the bushmeat supply chain. 
Generally unfit men, women and minors were excluded from this profession. The student test revealed that the means of hunters' age is significantly larger than wholesalers' age mean $(\mathrm{p}$-value $=0.006873$ ) and was highly variable. A previous research found that $55 \%$ of men over 15 years old identified as hunters in the Ivory Coast and that the age class between 21 and 40 years old represented $52 \%$ of them [35]. In our case $52.38 \%$ belonged to an age class of $20-39$. We assumed that, at this age bracket, a man takes on his responsibility as the head of household and becomes the main supplier for his progeny; he must struggle for the welfare of the family.

Their education levels extended from illiterate all the way up to university trained (Figure 3), yet the majority of hunters (52\%) had only a primary school education or less. Only $11.9 \%$ of the hunters had graduated from secondary school. Globally there was no difference between wholesalers and hunters' education level (Pearson Chi-Square, $\mathrm{p}$-value $=0.57$ ). In Brazzaville, four percent of sellers had reached university level and 33\% had diplomas from secondary school [36].

While it may seem astounding for a university degree holder engaged in the commercial sale of bushmeat, it is real since the lack of employment in many forest regions of Africa, families often have few assets on which to rely [6] [19]. To maintain a reasonable standard of living, some of them combine multiple activities or professions (hunting, agriculture, fishing, teaching, etc.).

The majority of hunters detained expired hunting permit (60\%), valid (33.33\%) and without $(6.67 \%)$. So the legislation appeared not to be applied rigorously as the service responsible of hunting shotgun control (the national security agency) should regularly verify expired permit and require hunters for its renewal. Surprisingly this fact and their low education level didn't have any impact on the knowledge of national legislation about protected species ( $p$-value: 0.495). Cited species (Figure 4) were not equitably known by hunters as protected, yet all of them are present on the list of totally and partially protected animals of DRC, except the viper which, is not a protected animal in DRC and its conservation status in IUCN remains NE (not evaluate, Appendix 1).

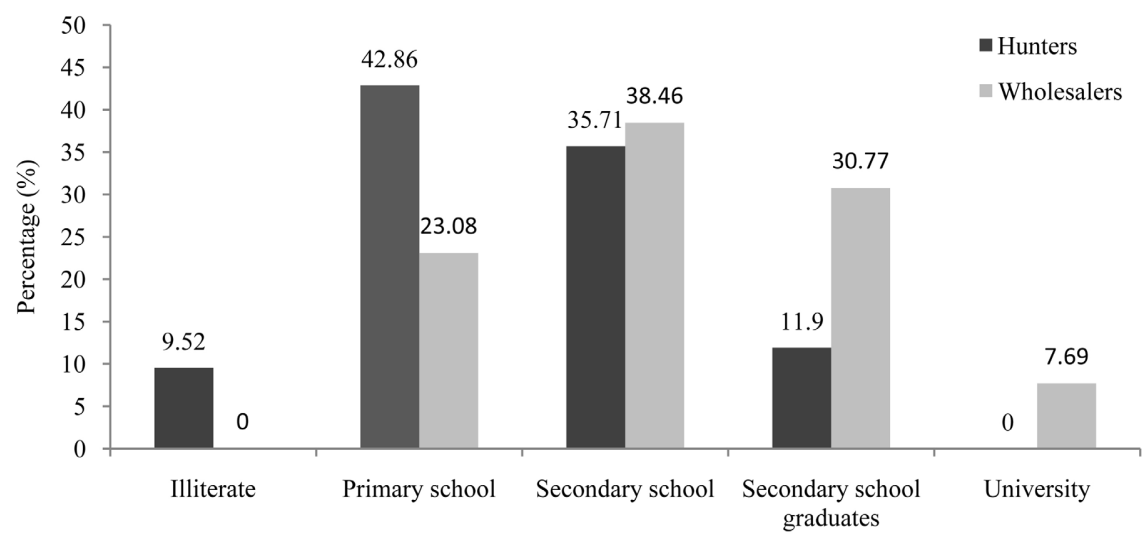

Figure 3. Education level of actors. 


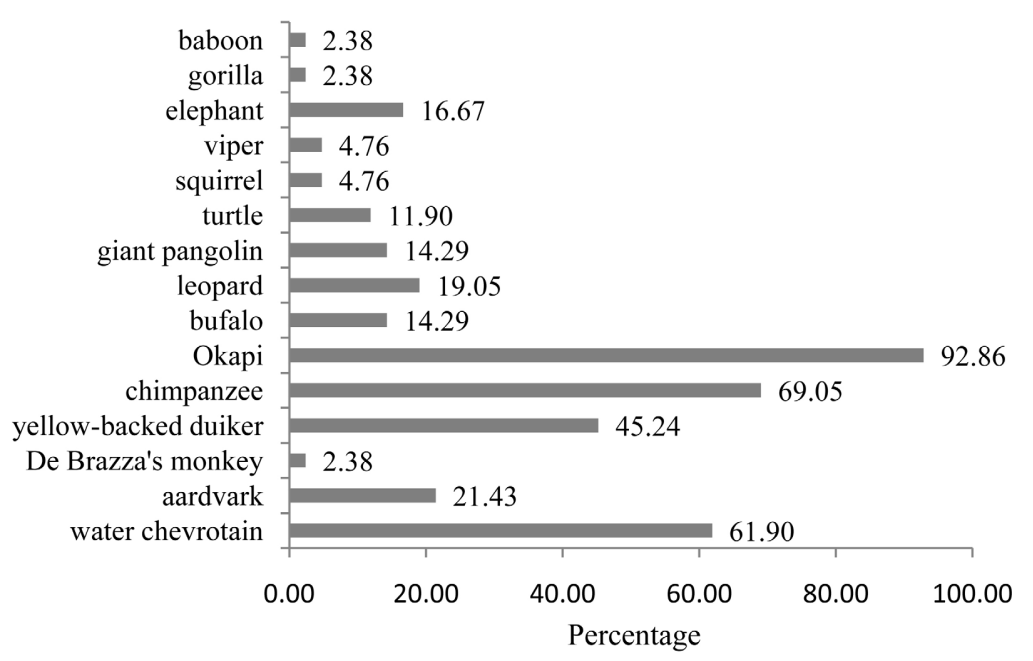

Figure 4. Animals known by hunters as protected.

Knowledge of national regulations related to bushmeat activities always been limited for some actors in villages [37]. According to DRC hunting law [38], there are three status categories for wild animals: totally protected, partially protected and non-protected. The rural hunting license, allows only the use of traditional tools and traps, prohibits the use of sophisticated firearms, but the 12-gauge shotguns only can be used.

Hunters should only capture non-protected species and a limited number is required. The chief of village has a responsibility to enact these hunting regulations in his jurisdiction. However, some totally protected species in DRC were hunted (e.g., Pan troglodytes, Hyemoschus aquaticus, Orycteropus afer) and partially protected species (e.g., Potamochoerus porcus and Phataginus tricus$p i s$ ), bringing out that hunting laws were not strictly respected. Whilst wholesalers and hunters have an association, bushmeat policies are not discussed among them.

\subsection{Supply of Wholesalers and Commercial Circuit}

Wholesalers live generally in city of Kisangani (92.31\%), the rest in their supply sites. The mean time spent in a village during game collection was 3.5 days (SD: 1.26). They typically circulated among villages on motorcycles with baskets for recognition (Figure 5). When bushmeat is abundant in the villages, they spend only two days doing their supply; yet, in cases of scarcity, they may remain for up to five days. Bushmeat collection occurs with motorcycles for most of them, and simultaneously more motorcycles than vehicles in the supply of bushmeat toward urban centers in Ghana were noted [31].

As the preservation state of the bushmeat is a factor not to be neglected; potential damage of the meat is a clear factor limiting the number of days taken to gather the game. Even smoked, it can be affected by effects of equatorial climate factors [12], and generate conservation challenges. This issue, combined with the fact that most wholesalers do not have a large supply of reserve funds, leads to a 

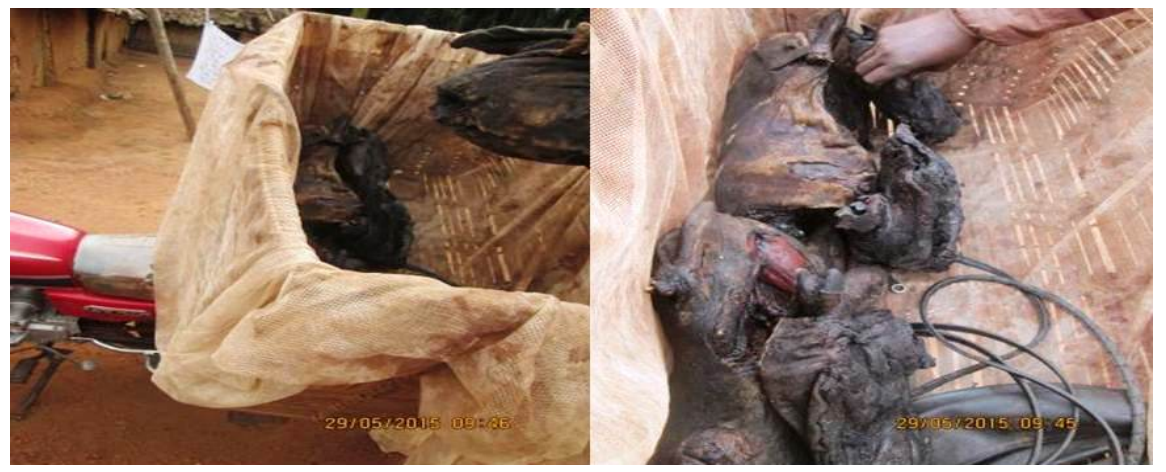

Figure 5. Wholesaler supplying bushmeat (Images credited to the author).

quick supply rotation of two to three days. However, the meat nearly to be decomposed was continually dried by the wholesalers over a fire, using a suspended grid (Appendix 3).

A case of a contract between the hunter and a wholesaler was revealed. Typically all game was collected if they agree on a reasonable price, as it was the case in Guinea [13]. In the villages, wholesalers maintain the initial purchased bushmeat in mosquito nets (Figure 5) for protection against insects which can bring parasites, while waiting for additional game. A cargo for a wholesaler has an estimated value of 350,000 to 600,000 Congolese franc (376.34 to 645.16 US\$) dependent on the purchasing power. However, some hunters bring their bushmeat to the urban market in Kisangani to sell directly to retailers (14.46\% of bushmeat hunted).

The bushmeat supply chain in this region is relatively complex, with numerous actors operating at multiple scales (Figure 6). Hunters are the key element in the bushmeat circuit within the Congo basin forest, various people buy game from them, which makes bushmeat sale more diversified. In Brazzaville, three types of groupings among the mediators, according the final use of the purchased bushmeat were found [39]. Those findings first distinguishe the wholesale suppliers who sell the entire purchased product, the half-wholesalers, suppliers who sell a portion of their purchased bushmeat to the retailers and finally, the retailers who sell in urban markets. Likely, others researchers recognized that the bushmeat commercial circuit in Cameroon is filled by different inhabitants and schematized in a simple way, with three kinds of actors: hunters, mediators and consumers [40]. Their findings revealed also sellers directly supplied by hunters. Nevertheless, still in DRC, contrary results in which hunters sold bushmeat to specific villagers called "collectors" were found along the road [41].

While the largest proportion was sold (82.85\%), $11.96 \%$ was consumed; this consumption is both for hunters in forest and for their family in villages, and almost the half of this proportion was consumed for being supposed so tasty. Gifted proportion was $5.19 \%$ and mostly the less lucrative game that is consumed or given to relatives like snakes, birds, elephant shrews as they are small sized animals. Bushmeat and fish are predominantly sold at the market rather than consumed within DRC households [42]. Nonetheless, it has been realized 


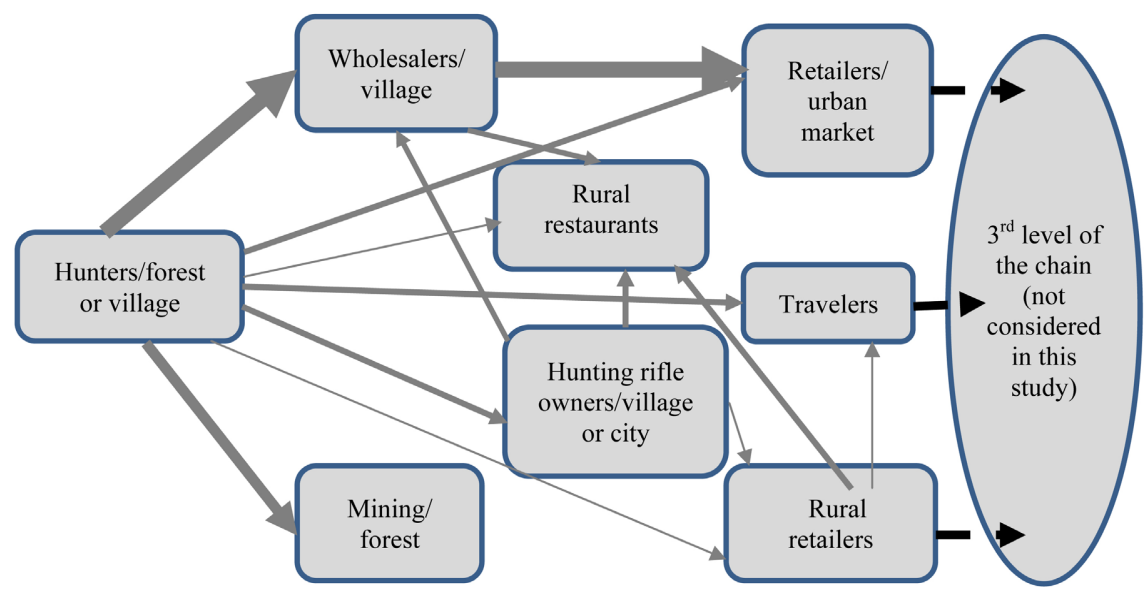

Figure 6. Commercial circuit on the first and second levels of the bushmeat supply chain (Arrows thickness show the pace of the transaction between actors).

that a large fraction was for subsistence while sale and multiple destinations (gifts, legacies and religious offerings) were less represented in a village of Chad [43]. The livelihood in each region can influence the situation. In cases where hunters have others principal activity, a higher percentage of hunting products might not be sold, bushmeat forms a moderate component of household income source, if not a very important component of incomes particularly for the poor families [42]. Further researchers have also made comparisons between different proportions (Table 1). Although it is not clearly explained how consumed meat was distinguished from sold meat in that table, the results of previous research in DRC approve findings of this research.

Within the proportion to be sold, the primary driver was financial profitability with $87.86 \%$ (Figure 7), followed by palatability of the game with five percent, (some animals are not sold because they are delectable) and existing taboos (4.76\%; others are forbidden for wholesalers to touch, eat, exploit, etc., due to custom or tradition) then religious taboos or customs can also affect the sale of an animal but likely only contribute to its protection if an animal is doubly forbidden: both to kill and to eat. Wholesalers' preference was only the primary factor in $2.38 \%$ of sales decisions.

Bushmeat can be sold to a wide range of buyers (Figure 8), but direct sale to wholesalers describes the largest sales percentage of 55.75\%. Villagers, travellers and rural restaurants each represent less than five percent of bushmeat sales, while miners use $16.55 \%$. The term "rurban" was conceived [27] (coming from rural and urban) to designate the mineworkers; they live in forest with the same quantity of bushmeat consumption as the urban. For a survey in the DRC, the researcher noted that the sale depends mainly on presence of the commercial circuits, particularly a functional transportation system, the presence of markets and consumers [10].

For the sedentary population of a village in Chad, bushmeat is largely destined for subsistence consumption, with the surplus sale of some species like warthog, aardvark and ostrich, which are not consumed for any reason [43]. 


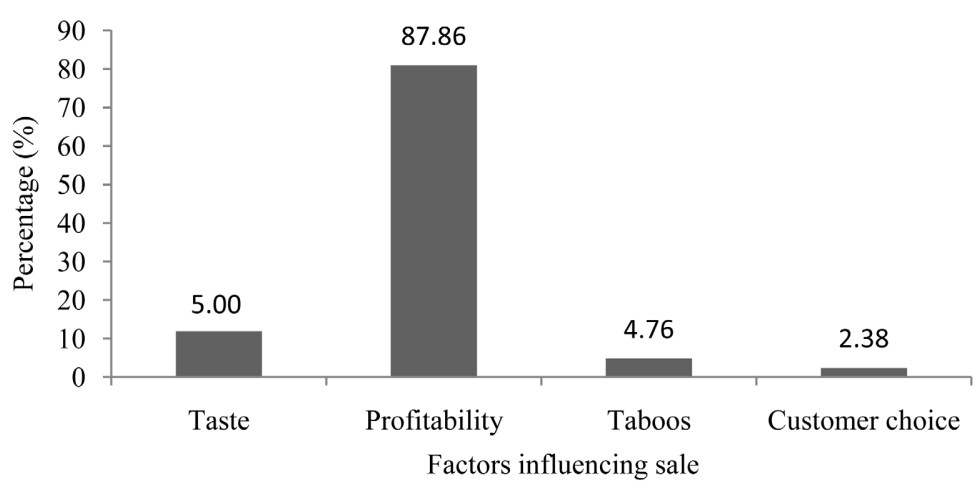

Figure 7. Factors influencing the sale of bushmeat.

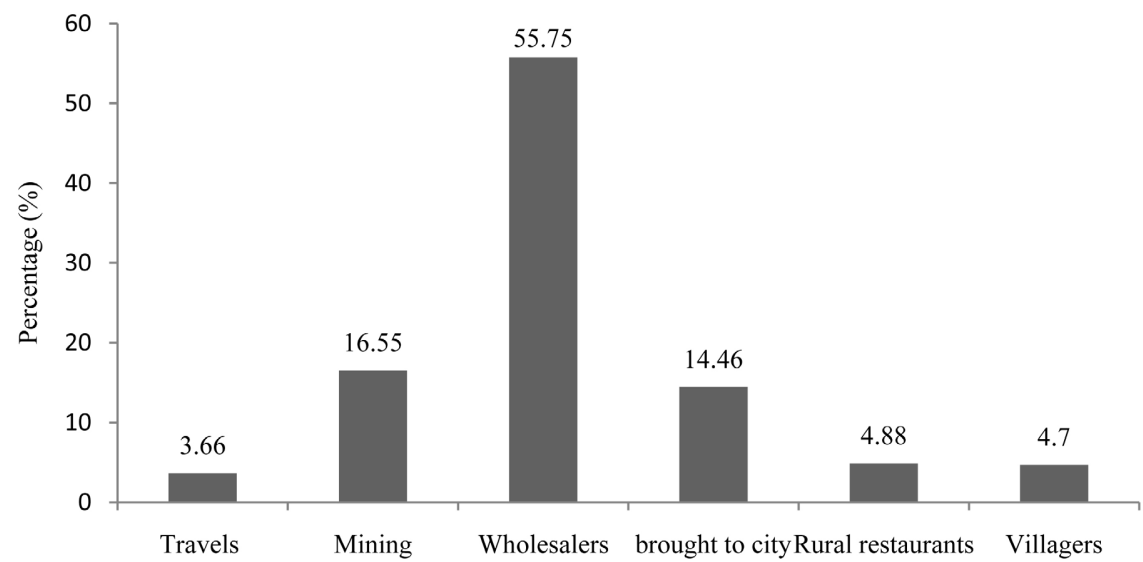

Figure 8. Different types of bushmeat sales.

Table 1. Consumption and sold quantities (In percentage) of bushmeat in the Congo basin region.

\begin{tabular}{cccc}
\hline Country & Local consumption & Sold & Sources \\
\hline Congo & 28 & 68 & [27] (Delvingt, 2001) \\
CAR & 65 & 35 & [27] (Delvingt, 2001) \\
DRC & 10 & 90 & [42] (De Merode et al., 2003) \\
Gabon & 60 & 40 & [29] (Van Vliet and Nasi, 2008) \\
Equatorial Guinea & 10 & 90 & [44] (Kümpel, 2006) \\
Cameroon & 36 & 64 & [45] (Wright and Priston, 2010) \\
\hline
\end{tabular}

The majority of sale occurred through cash transactions (88.09\%) with the remainder proportion based on barter, which was trade for cartridges in all cases. Expenses covered by earnings from bushmeat sale are various according to hunters (Figure 9). Diverse needs in hunters' households are covered by these incomes. The renewal of hunting equipment, foods, education, and health bills were priorities.

\subsection{Impact of Hunting Activities on Animal Diversity}

Answering the question "is this hunting sustainable?" it is imperative to collect 


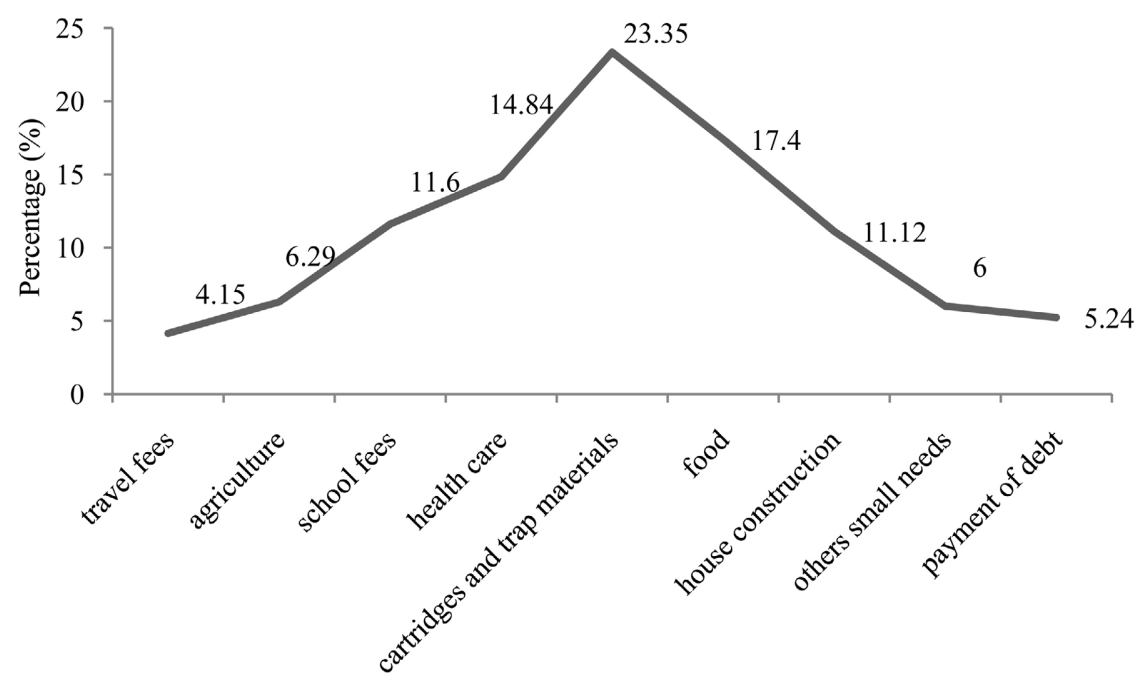

Figure 9. Expenses covered by hunting incomes (According to hunters).

data and estimate hunting effects on wildlife [46]. For a sustainable hunting, hunters' yield must not cause local extinction of animal populations or disrupt the overall functioning of the ecosystem [47]. Significant difference revealed a negative effect of hunting on wild animal ( $p$-value $<0.01$ ) for the two average distances from the village to a location where a medium or large-sized mammal can be encountered, comparing interview data between the 1990s and 2015 (Figure 10(a)), test result: paired t-test: data: $\mathrm{t}=-8.3417, \mathrm{df}=41, \mathrm{p}<0.001$. The same result was found in the comparison of interview data for the 1990s and the fieldwork data, test result: two sample $\mathrm{t}$-test data: $\mathrm{t}=-9.0359, \mathrm{df}=100.357, \mathrm{p}<$ 0.001 , (Figure 10(b)). The last test (Figure 10(c)), with a result of the two sample $\mathrm{t}$-test data: $\mathrm{t}=2.3742, \mathrm{df}=81.691, \mathrm{p}=0.01993$, was calculated between the interview results about the distance in 2015 and the fieldwork conducted with hunters during this research. A positive and strong correlation (Figure 10(d)) was found between distance and captured animals, $\mathrm{R}=0.81337$ and the coefficient of determination (R2) was 0.6616 ; thus, the distance explained $66.16 \%$ of the animals hunted.

Species' abundance changes with distance to village and roads [48] and effective hunting occurred more than $10 \mathrm{~km}$ from villages [29]. Conversely, other drivers should be considered, such as the growth of agricultural areas and mining exploitation, they always create an imbalance and habitat fragmentation [49] [50], and species can move from one area to another. In fragmented areas, wildlife is more vulnerable to hunting [51] [52] [53] than those inhabiting intact forest areas.

In general, it was not evident to make a decision on whether or not hunting in this area is unsustainable, as the effect of hunting activities on biodiversity is still a complex event that varies in space and over time, and finite studies are not yet available about this effect [54], many parameters need to be well understood [22]. Nevertheless, our findings demonstrated that negative effects of hunting on biodiversity exist within these villages. 


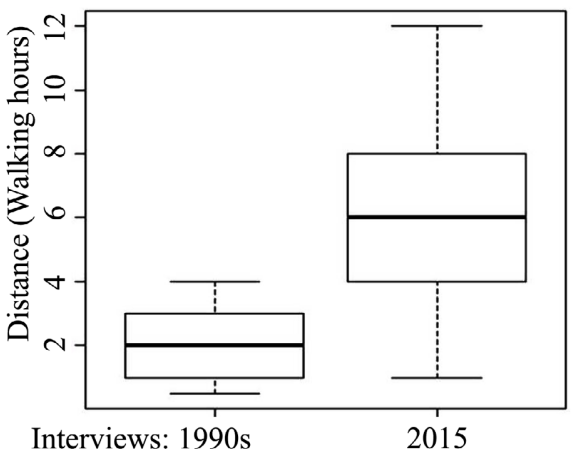

(a)

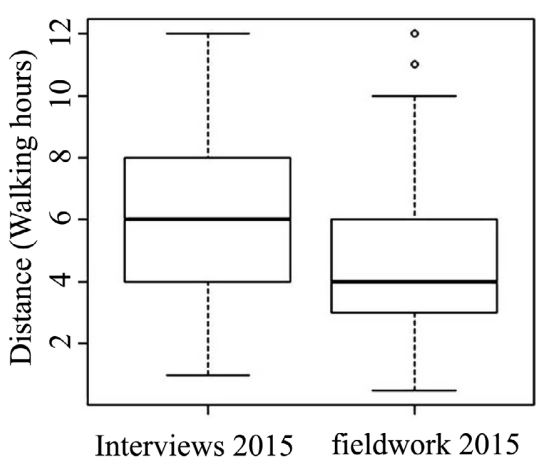

(c)

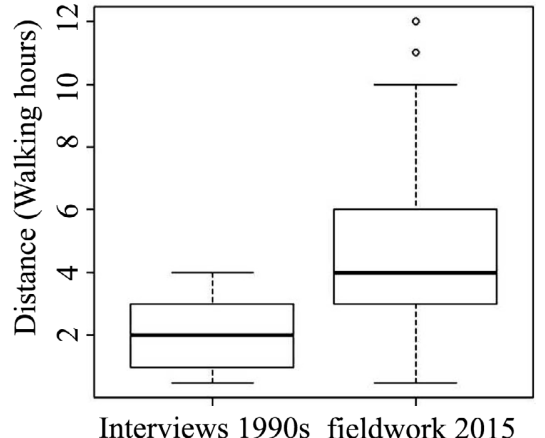

(b)

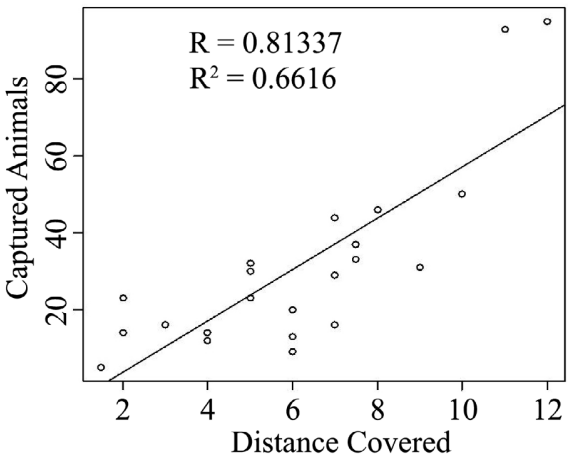

(d)

Figure 10. Hunting effect on wild fauna and correlation between distance and captured.

\section{Conclusions}

The bushmeat commercial circuit on Ituri road is complex, unstructured and can be reasonably classified as informal. A large portion of the bushmeat passes from hunters to wholesalers for sale in the Kisangani city market. Indeed, the overall primary objective is to finance food, health bills, agriculture and school fees for the hunters' families; this indicates the crucial characteristic of the activity for them and that their welfare depends on wildlife resources.

Recognition of this fact is essential when discussions of potential additional hunting regulations are proposed to further protect populations of hunted species, and this research identified some deficiencies in current laws and their enforcement as it relates to the hunting and the sale of bushmeat. The long-term affordability of conservation efforts and sustainable management depends on the social and political context within which they occur [55]; thus, it is important to the DRC's government to ensure a stable socio-political state in the whole country in general and particularly in regions with high biodiversity. The critical nature of bushmeat to the economy and livelihoods in this region, and in the DRC as a whole, stresses the importance of making sustainability and legality of these activities a primary goal, both from the standpoint of wildlife managers, the hunters and villagers themselves. It is obvious hunters want to continue hunting and therefore prioritize the tools of hunting activities among their potential expenses (cartridges and trapping materials). 
Therefore, several alternative opportunities should be initiated in the villages in order to reduce their dependency character on wildlife for household income. However, we suggest more studies, especially those using the MSY model, to demonstrate a sustainable state of hunting in this region.

\section{Acknowledgements}

This work was supported by a grant from the European Union, through the project "Forêts et Changement Climatique au Congo" (FCCC). We thank Dr. Joe KOLOWSKI for his multiple linguistic corrections, and anonymous language editors from SAGE language service; the hunters of Bafwaboli and Baegofoma villages for their collaboration, and the chiefs of villages.

\section{Conflicts of Interest}

The authors declare no conflicts of interest.

\section{References}

[1] Coad, L.M. (2008) Bushmeat Hunting in Gabon: Socio-Economics and Hunter Behavior. Ph.D. Dissertation, University of Cambridge, Cambridge.

[2] Nasi, R., Brown, D., Wilkie, D., Bennett, E., Tutin, C., Van Tol, G. and Christophersen, T. (2009) Conservation et utilisation des ressources fauniques: La crise de la viande de brousse. Secretariat of the Convention on Biological Diversity, Montreal.

[3] Golden, C.D., Fernald, L.C., Brashares, J.S., Rasolofoniaina, B.R. and Kremen. C. (2011) Benefits of Wildlife Consumption to Child Nutrition in a Biodiversity Hotspot. Proceedings of the National Academy of Sciences, 108, 19653-19656. https://doi.org/10.1073/pnas.1112586108

[4] Van Vliet, N. and Mbazza, P. (2011) Recognizing the Multiple Reasons for Bushmeat Consumption in Urban Areas: A Necessary Step toward the Sustainable Use of Wildlife for Food in Central Africa. Human Dimensions of Wildlife, 16, 45-54. https://doi.org/10.1080/10871209.2010.523924

[5] Fischer, A., Sandström, C., Delibes-Mateos, M., Arroyo, B., Tadie, D., Randall, D., Hailu, F., Lowassa, A., Msuha, M., Kereži, V., Reljić, S., Linnell, J. and Majić, A. (2013) On the Multifunctionality of Hunting-An Institutional Analysis of Eight Cases from Europe and Africa. Journal of Environmental Planning and Management, 56, 531-552. https://doi.org/10.1080/09640568.2012.689615

[6] Bowen-Jones, E., Brown, D. and Robinson, E.J. (2003) Economic Commodity or Environmental Crisis? An Interdisciplinary Approach to Analyzing the Bushmeat Trade in Central and West Africa. Area, 35, 390-402.

https://doi.org/10.1111/j.0004-0894.2003.00189.x

[7] Brashares, J.S., Arcese, P., Sam, M.K., Coppolillo, P.B., Sinclair, A.R. and Balmford, A. (2004) Bushmeat Hunting, Wildlife Declines, and Fish Supply in West Africa. Science, 306, 1180-1183. https://doi.org/10.1126/science.1102425

[8] Nasi, R., Taber, A. and Van Vliet, N. (2011) Empty Forests, Empty Stomachs? Bushmeat and Livelihoods in the Congo and Amazon Basins. International Forestry Review, 13, 355-368. https://doi.org/10.1505/146554811798293872

[9] Van Vliet, N., Nebesse, C. and Nasi, R. (2015) Bushmeat Consumption among Rural and Urban Children from Province Orientale, Democratic Republic of Congo. Oryx, 49, 165-174. https://doi.org/10.1017/S0030605313000549 
[10] Valimahamed, A. (2014) La chasse villageoise en République Démocratique du Congo: Une évaluation économique et financière de la filière viande de brousse. Bushmeat Project, Center for International Forestry Research, Kinshasa.

[11] Lescuyer, G. (2013) Evaluation économique de la chasse villageoise au Cameroun. In: Atyi, R.E.A., Lescuyer, G., Poufoun, J.N. and Fouda, T.M., Eds., Etude de l'importance économique et sociale du secteur forestier et faunique au Cameroun, Center for International Forestry Research, Yaoundé, 21 p.

[12] Fargeot, C. (2009) Le commerce de la viande de chasse en Afrique Centrale: Etude d'un marché-porte: Le pk 12 à Bangui (RCA). Paper Presented at the Colloque SFER Chasse, Territoires et Développement durable Outils d'analyse, enjeux et perspectives.

[13] Dia, M. (2005) Gestion de la faune sauvage: Evaluation de la problématique de la viande de brousse en Guinée. Food Agriculture Organisation, Romes.

[14] Ringuet, S., Van Vliet, N., Melisch, R. and Ngandjui, G. (2010) Developpement d'un système de suivi de la viande de brousse en Afrique Centrale. TRAFFIC International, Cambridge Press, Cambridge.

[15] Vheiye, G.M., Massamba, J., Massamba, A. and Silou, T. (2011) Consommation de la viande de brousse dans la zone du Parc National de Conkouati-Douli, Congo (Brazzaville): Nature du gibier et modalités de consommation. Tropicultura, 29, 131-137.

[16] van Vliet, N., Nebesse, C., Gambalemoke, S., Akaibe, D. and Nasi, R. (2012) The Bushmeat Market in Kisangani, Democratic Republic of Congo: Implications for Conservation and Food Security. Oryx, 46, 196-203. https://doi.org/10.1017/S0030605311000202

[17] Abernethy, K.A., Coad, L., Taylor, G., Lee, M.E. and Maisels, F. (2013) Extent and Ecological Consequences of Hunting in Central African Rainforests in the Twenty-First Century. Philosophical Transactions of the Royal Society B, 368, 1-13. https://doi.org/10.1098/rstb.2013.0494

[18] Wilkie, D.S. and Carpenter, J.F. (1999) Bushmeat Hunting in the Congo Basin: An Assessment of Impacts and Options for Mitigation. Biodiversity Conservation, 8, 927-955. https://doi.org/10.1023/A:1008877309871

[19] Bennett, E.L., Blencowe, E., Brandon, K., Brown, D., Burn, R.W., Cowlishaw, G., Davies, G., Dublin, H., Fa, J.E., Milner-Gulland, E.J., Robinson, J.G., Rowcliffe, M., Underhood, F.M. and Wilki, D.S. (2007) Hunting for Consensus: Reconciling Bushmeat Harvest, Conservation, and Development Policy in West and Central Africa. Conservation Biology, 21, 884-887. https://doi.org/10.1111/j.1523-1739.2006.00595.x

[20] Goodall, J. (2005) Viande de brousse: La crise, aujourd'hui, le trafic de viande de brousse est la plus importante et immédiate menace pour la faune sauvage africaine. Feuillet de documentation, Jane Goodall Institute, Toronto.

[21] Bodmer, R.E., Fang, T.G., Moya, L. and Gill, R. (1994) Managing Wildlife to Conserve Amazonian Forests: Population Biology and Economic Considerations of Game Hunting. Biological Conservation, 67, 29-35. https://doi.org/10.1016/0006-3207(94)90005-1

[22] Robinson, J.G. and Redford, K.H. (1994) Measuring the Sustainability of Hunting in Tropical Forests. Oryx, 28, 249-256. https://doi.org/10.1017/S0030605300028647

[23] Brown, D. (2003) Bushmeat \& Poverty Alleviation: Implications for Development Policy. Wildlife Policy Briefing, 1, 1-4.

[24] Muller-Landau, H.C. (2007) Predicting the Long-Term Effects of Hunting on Plant 
Species Composition and Diversity in Tropical Forests. Biotropica, 39, 372-384. https://doi.org/10.1111/j.1744-7429.2007.00290.x

[25] Fa, J.E., Currie, D. and Meeuwig, J. (2003) Bushmeat and Food Security in the Congo Basin: Linkages between Wildlife and People's Future. Environmental Conservation, 30, 71-78. https://doi.org/10.1017/S0376892903000067

[26] Redford, K.H. (1992) The Empty Forest. BioScience, 42, 412-422. https://doi.org/10.2307/1311860

[27] Delvingt, W. (2001) La forêt des hommes: Terroirs villageois en forêt tropicale africaine. Presses Agronomiques de Gembloux, Belgium.

[28] Puit, M., Huart, A. Leroy, P. and Nsangou, N. (2004) Dynamique de la filière viande de brousse dans la partie continentale du Rio Muni en Guinée équatoriale. Tropicultura, 22, 204-210.

[29] Van Vliet, N. and Nasi, R. (2008) Hunting for Livelihood in Northeast Gabon: Patterns, Evolution, and Sustainability. Ecology and Society, 13, Article No. 33. https://doi.org/10.5751/ES-02560-130233

[30] Damania, R., Milner-Gulland, E.J. and Crookes, D.J. (2005) A Bioeconomic Analysis of Bushmeat Hunting. Proceedings of the Royal Society of London B Biological Sciences, 272, 259-266. https://doi.org/10.1098/rspb.2004.2945

[31] Cowlishaw, G., Mendelson, S. and. Rowcliffe, J.M. (2005) Structure and Operation of a Bushmeat Commodity Chain in Southwestern Ghana. Conservation Biology, 19, 139-149.

[32] Ndjele, M.B. (1988) Les éléments phytogéographiques endémiques dans la flore vasculaire du Zaïre. Ph.D. Dissertation, Université libre de Bruxelles, Bruxelles.

[33] Kingdon, J. (1997) The Kingdon Field Guide to African Mammals. Bloomsbury Publishing, London.

[34] Kingdon, J. (2006). Guide des mammifères d'Afrique: Plus de 300 espèces illustrées. Delachaux et Niestlé, France.

[35] Caspary, H.U. (1999) Wildlife Utilization in Côte d'Ivoire and West Africa. Potentials and Constraints for Development Cooperation.

[36] Mbete, R.A., Banga-Mboko, H., Ngokaka, C., Bouckacka III, Q.F., Nganga, I., Hornick, J.L., Leroy, P. and Vermeulen, C. (2011) Profil des vendeurs de viande de chasse et évaluation de la biomasse commercialisée dans les marchés municipaux de Brazzaville Congo. Tropical Conservation Science, 4, 203-217. https://doi.org/10.1177/194008291100400208

[37] Anadu, P.A., Elamah, P.O. and Oates, J.F. (1988) The Bushmeat Trade in Southwestern Nigeria: A Case Study. Human Ecology, 16, 199-208. https://doi.org/10.1007/BF00888092

[38] Estève, J., Morin, E., Marin, A., Bergonzini, J., Lanly, J., Pellerin, M. and Tadjuidje, M. (2007) Étude comparative des textes législatifs et réglementaires relatifs à la gestion de la faune et de la chasse dans cinq pays du bassin du Congo. Cameroun, Congo, Gabon, RCA et RDC. État, analyse et perspectives. Silva, Riat.

[39] Malonga, R. (1996) Suivi du marché de viande de brousse à Brazzaville (République du Congo). Wildlife Conservation Society, Brazzaville.

[40] Lescuyer, G. and Nasi, R. (2016) Financial and Economic Values of Bushmeat in Rural and Urban Livelihoods in Cameroon: Inputs to the Development of Public Policy. International Forestry Review, 18, 93-107. https://doi.org/10.1505/146554816819683726

[41] Waloimi, N. (2013) Commercialisation de la viande de brousse: Enjeux de la bonne 
gouvernance des ressources naturelles en Province Orientale, République Démocratique du Congo. MSc. Dissertation, University of Kisangani, Kisangani.

[42] De Merode, E., Homewood, K. and Cowlishaw, G. (2003) Wild Resources and Livelihoods of Poor Households in Democratic Republic of Congo. Wildlife Policy Briefing, 1, 25-28.

[43] Alde, A.D. and Abdoulaye, F. (2003) Utilisation des ressources naturelles: La consommation de la viande de brousse autour du Parc National de Zakouma au sud-est Tchad cas du village Kacha-kacha: Laboratoire de recherche veterinaires et zootechniques de Farcha, Djamena.

[44] Kümpel, N.F. (2006) Incentives for Sustainable Hunting of Bushmeat in Río Muni, Equatorial Guinea. Ph.D. Dissertation, University of London, London.

[45] Wright, J.H. and Priston, N.E. (2010) Hunting and Trapping in Lebialem Division, Cameroon: Bushmeat Harvesting Practices and Human Reliance. Endangered Species Research, 11, 1-12. https://doi.org/10.3354/esr00244

[46] Robinson, J. and Bennett, E.L. (2000) Hunting for Sustainability in Tropical Forests. Columbia University Press, New York.

[47] Robinson, J.G. and Redford, K.H. (1991) The Use and Conservation of Wildlife. In: Robinson, J.G. and Robinson, K.H., Eds., Neotropical Wildlife Use and Conservation, University of Chicago Press, Chicago, 3-5.

[48] van Vliet, N., Nebesse, C., Gambalemoke, S., Akaibe, D. and Nasi, R. (2012) The Bushmeat Market in Kisangani, Democratic Republic of Congo: Implications for Conservation and Food Security. Oryx, 46, 196-203.

https://doi.org/10.1017/S0030605311000202

[49] Peres, C.A. (2001) Synergistic Effects of Subsistence Hunting and Habitat Fragmentation on Amazonian Forest Vertebrates. Conservation Biology, 15, 1490-1505. https://doi.org/10.1046/j.1523-1739.2001.01089.x

[50] Mathevet, R. and Tamisier, A. (2002) Creation of a Nature Reserve, Its Effects on Hunting Management and Waterfowl Distribution in the Camargue (Southern France). Biodiversity Conservation, 11, 509-519. https://doi.org/10.1023/A:1014860617353

[51] Turner, I.M. and Corlett, R.T. (1996) The Conservation Value of Small, Isolated Fragments of Lowland Tropical Rain Forest. Trends in Ecology \& Evolution, 11, 330-333. https://doi.org/10.1016/0169-5347(96)10046-X

[52] Cullen Jr., L., Bodmer, R.E. and Pádua, C.V. (2000) Effects of Hunting in Habitat Fragments of the Atlantic Forests, Brazil. Biological Conservation, 95, 49-56. https://doi.org/10.1016/S0006-3207(00)00011-2

[53] Poulsen, J.R., Clark, C.J., Mavah, G. and Elkan, P.W. (2009). Bushmeat Supply and Consumption in a Tropical Logging Concession in Northern Congo. Conservation Biology, 23, 1597-1608. https://doi.org/10.1111/j.1523-1739.2009.01251.x

[54] Grignolio, S., Merli, E., Bongi, P., Ciuti, S. and Apollonio, M. (2011) Effects of Hunting with Hounds on a Non-Target Species Living on the Edge of a Protected Area. Biological Conservation, 144, 641-649. https://doi.org/10.1016/j.biocon.2010.10.022

[55] Hanson, T., Brooks, T.M., Da Fonseca, G.A., Hoffmann, M., Lamoreux, J.F., Machlis, G., Mittermeier, C.G., Mittermeier, R.A. and Pilgrim, J.D. (2009) Warfare in Biodiversity Hotspots. Conservation Biology, 23, 578-587. https://doi.org/10.1111/j.1523-1739.2009.01166.x 


\section{Appendix 1}

Table A1. Hunted Species found during the regular visit paid to hunters.

\begin{tabular}{|c|c|c|c|c|}
\hline Species & $\begin{array}{l}\text { Status protection } \\
\text { in DRC }\end{array}$ & $\begin{array}{l}\text { IUCN } \\
\text { status }\end{array}$ & Total & $\begin{array}{c}\text { Percentage } \\
(\%)\end{array}$ \\
\hline Cercopithecus I hoesti ${ }^{*}$ & none & VU & 123 & 17.7 \\
\hline Cercopithecus sp. ${ }^{\star}$ & none & - & 118 & 17.0 \\
\hline Cercopithecus ascanius ${ }^{*}$ & none & LC & 112 & 16.4 \\
\hline Cephalophus monticola* & none & $\mathrm{LC}$ & 69 & 9.9 \\
\hline Cercopithecus denti ${ }^{*}$ & none & LC & 68 & 9.8 \\
\hline Atherurus africanus* & none & LC & 41 & 5.9 \\
\hline Cephalophus dorsalis* & none & LC & 40 & 5.7 \\
\hline Cercopithecus hamlyni & none & VU & 20 & 2.8 \\
\hline Rhynchocyon cirneit & none & NT & 19 & 2.7 \\
\hline Lophocebus aterrinus* & none & $\mathrm{NE}$ & 15 & 2.1 \\
\hline Cricetomys emint ${ }^{*}$ & none & $\mathrm{LC}$ & 13 & 1.8 \\
\hline Potamochoerus porcus ${ }^{\star}$ & partial & $\mathrm{LC}$ & 11 & 1.5 \\
\hline Cercopithecus neglectus ${ }^{\star}$ & none & $\mathrm{LC}$ & 8 & 0.8 \\
\hline Pan troglodytes ${ }^{\star}$ & total & $\mathrm{EN}$ & 5 & 0.7 \\
\hline Piliocolobus tholloni ${ }^{*}$ & none & $\mathrm{NE}$ & 4 & 0.5 \\
\hline Phataginus tricuspis* & partial & VU & 3 & 0.4 \\
\hline Papio anubis ${ }^{\star}$ & none & VU & 3 & 0.4 \\
\hline Numida meleagris** & none & LC & 3 & 0.4 \\
\hline Bycanistes albotibialis** & none & $\mathrm{NE}$ & 3 & 0.4 \\
\hline Varanus niloticus ${ }^{* * *}$ & none & $\mathrm{NE}$ & 3 & 0.4 \\
\hline Kinyxis erosa ${ }^{* * *}$ & none & $\mathrm{NE}$ & 3 & 0.4 \\
\hline Orycteropus afer ${ }^{*}$ & total & $\mathrm{LC}$ & 2 & 0.2 \\
\hline Galagoides sp.* & none & - & 2 & 0.2 \\
\hline Nandinia binotata ${ }^{*}$ & none & $\mathrm{LC}$ & 2 & 0.2 \\
\hline Hyemoschus aquaticus ${ }^{*}$ & total & $\mathrm{LC}$ & 1 & 0.1 \\
\hline Cephalophus sp.* & none & - & 1 & 0.1 \\
\hline Crossarchus alexandrit & none & $\mathrm{NE}$ & 1 & 0.1 \\
\hline Bitis gabonica ${ }^{* * *}$ & none & $\mathrm{NE}$ & 1 & 0.1 \\
\hline General total & & & 694 & 100 \\
\hline
\end{tabular}

DD: Data Deficient; EN: Endangered; LC: Least Concern; NE: Not Evaluate; NT: Near Threatened; VU: Vulnerable (International Union for Conservation of Nature [IUCN], 2016), and “-” means the species was not well identified so it wasn't possible to recognize its IUCN status. ${ }^{\star}$ Class of Mammals, ${ }^{*}$ Class of Birds, ${ }^{* * *}$ Class of Reptiles

\section{Appendix 2. Interview Guides}

\section{A. Summary of Interview questions with hunters}

Date: 
Locality:

Geographical coordinates:

Name (Optional):

Sex:

Age:

Marital status:

Education level:

Ethnic group:

Religion:

Residence:

Domestic composition

1. How long have you practice hunting? Except hunting, have you another activity?

a. yes b. no

2. Have an updated hunting license?

a. yes b. no

3. Do you hunt with your family's members?

a. yes b. no

4. Are there animals whose hunting is forbidden by the state?

a. yes b. no, if yes, list them.

Do you usually respect this measure?

a. yes b. no According to you, why this interdiction?

5. Are there animals whose hunting is forbidden by your custom?

a. yes b. no, if yes list them.

b. According to you, why this interdiction?

6. Are there periods during which hunting is forbidden?

a. yes b. no. If yes, which one?

7. According to you and your parents: how far from the village (after walking how long time) were the animals met (medium-sized mammals) in the years 1990s? And nowadays how is the situation?

8. Are there some zones where hunting is forbidden in your locality? a. yes b. no. If yes which one?

9. During what season hunting is prolific (month)?

10 . Who are your main customers and they come from where?

11. What is the period of profitable sale?

12. Do you have anything else to add?

B. Summary of the protocol of regular visit paid to hunters

1. Date of entry and exit in forest:

2. Species regularly captured:

a. Species more captured: b. Species rarely captured:

3. After how long time first animal was killed, and the total of hours/days by walking away the village.

4. Distribution of the games:

a. to sell b. to consume locally c. grants, d. all sold 
5. Factors intervening in this distribution:

a. size of the game b. clients' preferences c. financial profitability $d$. forbidden by customs.

6. More marketed species:

7. Verification if wholesalers are subscribers to hunters:

a. yes b. no. If yes is there an advance financing by material or by money?

8 Transactions mode between hunters and wholesalers:

a. by barter b. by the currency. If by barter what are articles (things) exchanged with the games?

9. Domains for the domestic investment in which the profit of hunting is spent:

10. Place of supplying in hunting materials after the sale of games:

11. Do you have anything else to add about this hunting campaign or the next one?

C. Summary of interview questions for wholesalers

Date:

Locality:

Geographical coordinates:

Name (Optional):

Sex:

Age:

Marital status:

Education level:

Ethnic group: ....

Religion:

Residence:

Domestic composition

1. How long have you practice this work? Do you have another financial activity except the sale of the bushmeat?

a. yes b. no

2. Are you subscribed at some hunters?

a. yes b. no

3. What type of relationship do you have with hunters?

a. family relationship b. friendship

4. Do you have some agreements signed with the hunters?

a. yes b. no. If yes what kind of agreements are they? And the supplying is it daily, after three days or weekly?

5. Do you buy all games brought by hunters or you can make a selection of some:

6. In which destination do you bring purchased bushmeat?

7. Have you a wholesalers' association?

8. Are you allowed to sell also in detail in the Kisangani city market?

a. yes b. no

9. At which distance supplying occur (from what village to which one)? 
10. Appropriate cargo ready to be brought to urban markets is equivalent to how many Congolese francs?

11. What are regularly difficulties meet in your job? Is there anything else you can add?

\section{Appendix 3. Some Images Took during Data Collection}

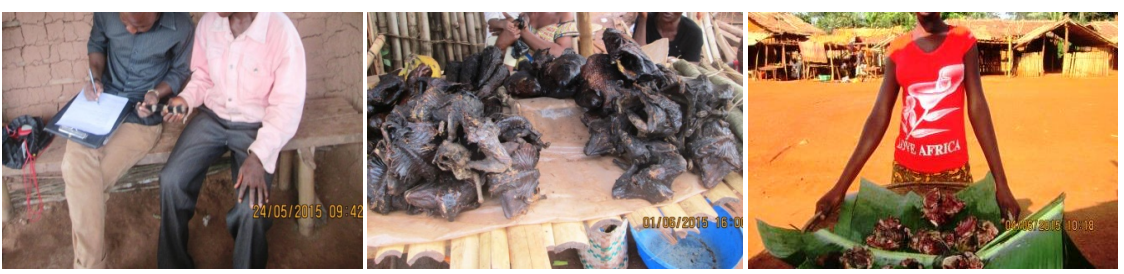

Left: interviewing a hunter, middle and right: Bushmeat retailers in village (Images credited to the authors).
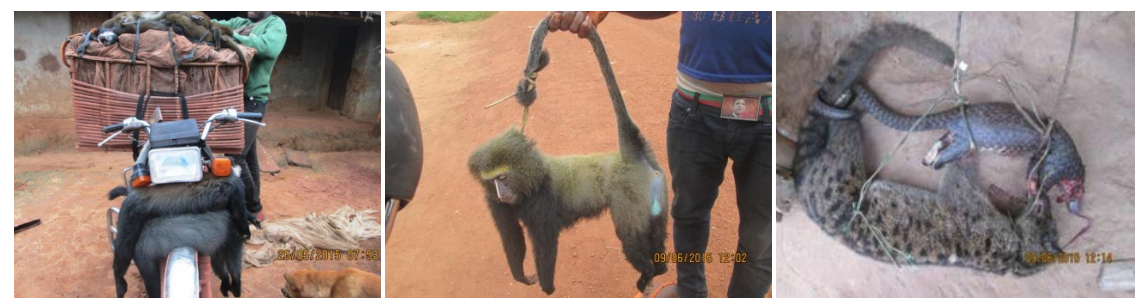

Left to right: a wholesaler making his cargo, a Cercopithecus hamlyni and Nandinia binotata \& Phataginus tricuspis hunted (Images credited to the authors).
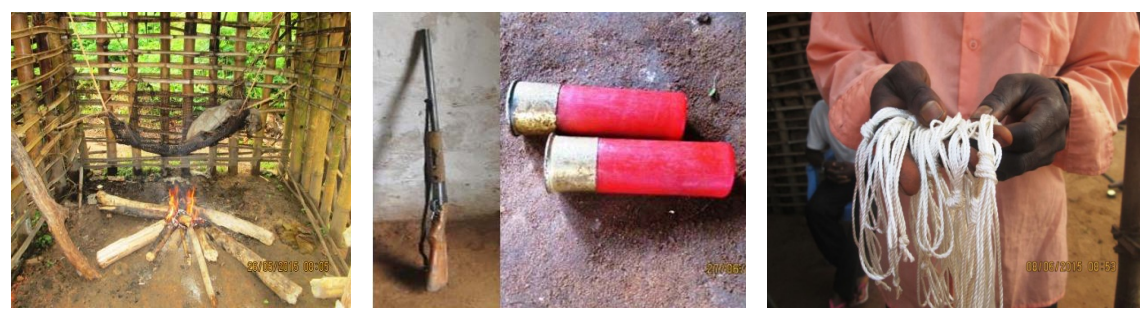

Left to right: bushmeat being dried on suspended grid, a rifle called "caliber 12" and its cartridges used in hunting and ropes used in trapping (Images credited to the authors).
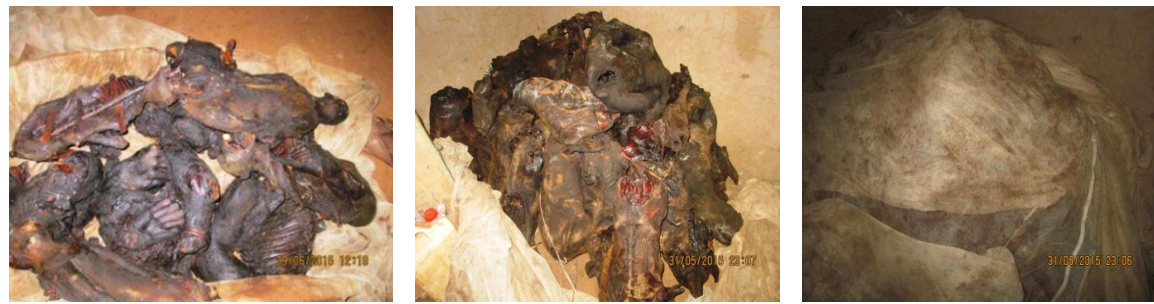

Left to right: Monkeys and chimpanzee's meat smocked, a bushmeat cargo of a wholesaler and a cargo protected by mosquito net (Images credited to the authors). 